\title{
PENERAPAN UNSUR TINDAK PIDANA PENCURIAN DENGAN KEKERASAN TERHADAP PELAKU ANAK OLEH PENYIDIK PADA SATRESKRIM POLRESTA PADANG
}

(Studi Pertimbangan Penyelesaian Perkara Anak Melalui Diversi)

\author{
Ori Friliansa Utama \\ Program Magister Ilmu Hukum,Universitas Ekasakti, Padang, Indonesia \\ Email: orifriliansa10@gmail.com
}

\begin{abstract}
Application of elements of the crime of theft with violence against child perpetrators by investigators at the Padang Police Satreskrim in the context of Consideration of Alternative Settlement of Child Cases where investigators are trying to apply ordinary theft criminal articles, so that the settlement of the theft case can be carried out by diversion, as in the case that occurred in Jalan Bandar Church, Kel Berok Nipah, West Padang District, Padang City. The victim refused to do diversion on the grounds that the value of the loss suffered was quite large. While in the case of the crime of theft, which occurred in a house, the child did the theft at night. The items taken are household appliances. For this crime, diversion can be carried out because the value of the loss is not large and the child already regrets his actions. The obstacle encountered by investigators in the application of elements of the crime of theft with violence against child perpetrators is that it is very difficult to rule out elements of violence in committing the crime of theft such as being carried out at night by damaging so that the act can be categorized as a criminal act of ordinary theft so that diversion can also be carried out. requires the willingness of the victim.
\end{abstract}

Keywords: Children, Diversion, Theft, Investigators

\begin{abstract}
ABSTRAK
Penerapan Unsur Tindak Pidana Pencurian Dengan Kekerasan Terhadap Pelaku Anak Oleh Penyidik Pada Satreskrim Polresta Padang dalam rangka Pertimbangan Alternatif Penyelesaian Perkara Anak dimana penyidik berusaha untuk menerapkan Pasal tindak pidana pencurian biasa, agar penyelesaian perkara pencurian tersebut dapat dilakukan secara diversi, sebagaimana pada kasus yang terjadi di jalan Bandar Gereja Kel Berok Nipah Kec Padang Barat Kota Padang. Korban menolak dilakukan diversi dengan beralasan nilai kerugian yang dideritanya cukup besar. Sementara pada Perkara tindak pidana Pencurian, yang terjadi di sebuah rumah, Anak melakukan pencurian pada malam hari. Barang barang yang diambil adalah peralatan rumah tangga. Terhadap tindak pidana ini dapat dilakukan diversi karena nilai kerugian yang tidak besar dan anak sudah menyesali perbuatannya. Kendala Yang Ditemui Penyidik Dalam Penerapan Unsur Tindak Pidana Pencurian Dengan Kekerasan Terhadap Pelaku Anak adalah sangat sulitnya mengenyampingkan unsur perbuatan kekerasan dalam melakukan tindak pidana pencurian seperti dilakukan pada malam hari dengan merusak agar perbuatan tersebut dapat dikategorikan sebagai tindak pidana pencurian biasa sehingga dapat dilakukan diversi yang juga memerlukan kesediaan korban.
\end{abstract}


Kata Kunci: Anak, Diversi, Tindak Pidana Pencurian, Penyidik

\section{PENDAHULUAN}

Orang merupakan insan sosial, karenanya orang orang itu tidak sendiri. Orang hidup berdampingan, apalagi bergerombolan serta bersamaan melangsungkan ikatan dampingi sesama. Ikatan ini terjalin bertepatan dengan keinginan hidup yang tidak bisa jadi senantiasa bisa dipadati sendiri. Keinginan hidup orang beragam. Pelampiasan keinginan hidup terkait dari hasil yang didapat lewat energi usaha yang dicoba buat mendapatkan kelimpahan serta keselamatan lahir serta hati. ${ }^{1}$ Situasi ini hendak bisa berhasil bila warga memiliki pemahaman buat bersikap asri dengan kebutuhan yang legal dalam kehidupan warga yang direalisasikan dengan berkelakuan laris cocok dengan norma yang legal di warga.

Sikap yang tidak cocok dengan norma ataupun bisa diucap selaku kecurangan kepada norma yang sudah disetujui nyatanya menimbulkan terganggunya kedisiplinan serta ketentraman kehidupan orang. Kecurangan yang begitu, umumnya oleh warga dicap selaku sesuatu pelanggaran apalagi kesalahan. Kesalahan dalam kehidupan warga ialah pertanda sosial yang hendak senantiasa dialami oleh tiap orang, warga, serta apalagi negara. ${ }^{2}$

Kesalahan perampokan ialah salah satu perbuatan kejahatan yang sangat kerap terjalin, banyaknya pemberitaan diberbagai alat massa bagus itu alat elektronik ataupun alat cap. Perbuatan kejahatan perampokan umumnya dilatarbelakangi oleh kondisi hidup pelakon tiap hari, misalnya kondisi ekonomi ataupun tingkatan pendapatannya yang terkategori kecil alhasil tidak bisa penuhi bayaran keinginan hidup tiap hari dan di mempengaruhi oleh tingkatan pembelajaran yang kecil. Dalam KUHP kesalahan perampokan dibedakan dengan bermacam kualifikasi antara lain begitu juga diatur dalam Artikel 365 KUHP ialah perampokan dengan kekerasan. Perampokan dengan kekerasan ialah kesalahan kepada harta barang. Kekerasan yang dicoba dalam perampokan itu memiliki tujuan buat mempersiapkan ataupun memudahkan perampokan ataupun bila terjebak terdapat peluang untuk sang pelakon buat melarikan diri biar benda yang dicuri itu senantiasa terletak di tangan pelakon.

Sebab kesalahan bukan cuma dicoba orang berusia, namun anak- anakpun bisa pula melaksanakan kesalahan yang bisa mudarat warga. Sebab anak ialah sesuatu anugerah Tuhan yang amat eksklusif untuk banyak orang yang telah berkeluarga, oleh sebab itu hingga penguasa di Indonesia sudah mempraktikkan Hukum Republik Indonesia No 35 Tahun 2014 mengenai Pergantian Atas Hukum Republik Indonesia No 23 Tahun 2003 mengenai Proteksi Anak, hendak namun tidak menuntut mungkin dengan terdapatnya Hukum Proteksi Anak, perihal itu dapat menjamin anak dapat bebas dari unsur- unsur pidana. Anak yang melaksanakan perbuatan kejahatan di cara bagi determinasi yang ada dalam Undang Undang Sistem Peradilan Kejahatan Anak ialah Undang undang No 11 tahun 2012 mengenai Sistem Peradilan Kejahatan Anak.

Anak muda mempunyai status serta andil yang berarti, dari kebutuhan keluarga, anak muda merupakan angkatan penerus yang sedia berkembang jadi berusia, selaku pewaris serta penerus keluarga. Ditatap dari kebutuhan negeri, paling utama untuk bangsa dannegara indonesia, anak muda serta anak muda biasanya, menemukan sebutan yang tidak dipunyai

\footnotetext{
${ }^{1}$ R. Abdoel Djamali, Pengantar Hukum Indonesia Edisi Revisi, Rajawali Pers, Jakarta, 2010, hlm 1.

${ }^{2}$ Bambang Waluyo, Pidana dan Pemidanaan, Sinar Grafika, Jakarta, 2008, hlm. 1.
} 
oleh angkatan yang lain ialah selaku tulang punggung negeri. Kenakalan anak muda bisa membatasi serta apalagi membatalkan usaha menciptakan anak muda serta angkatan yang bermutu. Hendak namun saat ini ini banyak anak anak muda yang beranjak jadi anak bandel, banyak di antara mereka yang melaksanakan tidakan yang melanggar hukum semacam permasalahan perampokan sebab hasrat mau mempunyai. Orang melaksanakan kesalahan sebab hasrat mau mempunyai telah memiliki predisposisi psikhis, tidak terdapat sesuatu kesalahan di warga yang tidak terdapat hubungannya dengan jiwa orang tetapi predisposisi ini selaku asumsi semata ${ }^{3}$.

Akar pokok yang diatur dalam Hukum Republik Indonesia No 11 Tahun 2012 merupakan pengaturan jelas hal kesamarataan Kestoratif serta Diversi yang dimaksudkan buat menjauhi serta menjauhkan Anak dari cara peradilan, alhasil bisa menjauhi stigmatisasi kepada anak yang berdekatan dengan hukum serta diharapkan anak bisa kembali ke dalam area sosial dengan cara alami. Oleh sebab itu, amat dibutuhkan kedudukan dan seluruh pihak dalam bagan menciptakan perihal itu. Cara itu wajib bermaksud pada terciptanya kesamarataan Restoratif, bagus untuk Anak ataupun untuk korban. Kesamarataan Restoratif yang diartikan dalam UndangUndang ini ialah sesuatu cara Diversi. Dalam Diversi seluruh pihak yang ikut serta dalam sesuatu perbuatan kejahatan khusus bersama- sama menanggulangi permasalahan dan menghasilkan sesuatu peranan buat membuat seluruh sesuatunya jadi lebih bagus dengan mengaitkan korban, Anak, serta warga dalam mencari pemecahan buat membenarkan, perdamaian, serta menentramkan batin, yang tidak bersumber pada bayaran.

Kayaknya perihal yang terjalin pada permasalahan masalah informasi No: LP atau 72 atau K atau II atau 2019 atau Zona Padang Barat, masalah perbuatan kejahatan perampokan dengan kekerasan dalam kesimpulan Artikel 368 serta Artikel 365 KUHP dengan mempunyai hasrat buat mempunyai HP korban alhasil memunculkan kehilangan buat korban bagus dengan cara modul serta psikologis. Aplikasi faktor yang dicoba oleh interogator amat pengaruhi alternative penentuan penanganan masalah anak yang hendak diaplikasikan. Apakah hendak menempuh system peradilan kejahatan ataukan lewat cara diversi, sebab salah satu ketentuan bisa dikerjakannya diversi merupakan bahaya kejahatan dari aksi yang dicoba anak tidak lebih dari 7 tahun.

Permasalahan yang akan dibahas adalah Penerapan dan permasalahan Unsur Tindak Pidana Pencurian Dengan Kekerasan Terhadap Pelaku Anak Oleh Penyidik Pada Satreskrim Polresta Padang dalam rangka Pertimbangan Alternatif Penyelesaian Perkara Anak?

\section{METODE PENELITIAN}

Spesifikasi penelitian adalah deskriptif analitis, dengan metode pendekatan yuridis normative didukung oleh yuridis empiris. Jenis data yang digunakan adalah data sekunder dan data primer. Data sekunder diperoleh dari studi dokumen, data primer diperoleh dengan cara wawancara. Data yang diperoleh kemudian dianalisa secara kualitatif .

\footnotetext{
${ }^{3}$ Abrianto Prakoso, Kriminologi dan Hukum Pidana Cet: 1, Laksbang Grafika,Yogyakarta, 2003, hlm
} 99. 


\section{PEMBAHASAN}

A. Penerapan Unsur Tindak Pidana Pencurian Dengan Kekerasan Terhadap Pelaku Anak Oleh Penyidik Pada Satreskrim Polresta Padang dalam rangka Pertimbangan Alternatif Penyelesaian Perkara Anak dengan diversi

Dalam pelaksanaan diversi yang dicoba oleh Satreskrim Polresta Padang awal mulanya melaksanakan perantaraan antara korban serta pelakon, mengaitkan BAPAS (Gedung Sosialisasi), Biro Sosial. Dalam penerapan penangkapan kepada anak yang melaksanakan perbuatan kejahatan perampokan dengan kekerasan diperlakukan beda dengan penangkapan yang dicoba pada orang berusia. Bila perantaraan dengan para pihak itu sukses hendak diadakan dengan skedul diversi cocok dengan peraturan yang sudah terdapat, sehabis skedul diversi itu sudah berakhir hingga kepolisian menghasilkan SP3 (Pesan Pemberhentian Investigasi) pada interogator. Dalam penangkapan itu mengaitkan penguasa wilayah ataupun diucap dengan simpan house. Supaya diversi bisa terselenggara hingga interogator wajib mempraktikkan faktor faktor perbuatan kejahatan yang bisa memudahkan pelakon.

Penerapan diversi kepada anak yang melaksanakan perbuatan kejahatan perampokan senantiasa dalam kontrol dari BAPAS, anak yang sudah dijadikan terdakwa serta hendak melaksanakan diversi tidak bisa pergi dari Padang bila ia tidak ditahan. Dasar ketetapannya merupakan Artikel 94 Hukum No 11 Tahun 2012 mengenai Sistem Peradilan Kejahatan Anak. Sedangkan itu, dalam determinasi melakukan diversi diatur dengan Peraturan Dewan Agung (PERMA) Republik Indonesia No 4 Tahun 2014 mengenai Prinsip Penerapan Diversi dalam Sistem Peradilan Kejahatan Anak yang diatur pada Artikel. ${ }^{4}$

Dari determinasi penerapan pada artikel di atas Satreskrim Polresta Padang telah melakukan dalam menanggulangi permasalahan perbuatan kejahatan yang dicoba oleh anak di dasar baya yang diupayakan dalam diversi. Dalam penerapan diversi ada kesamarataan, kesamarataan bagi John Rawls ialah bentuk dasar warga yang asli dimana hak- hak dasar, perbawa, independensi, pemasukan, peluang serta keselamatan terkabul.

Pemahaman hukum yang kecil atau besar dalam warga hendak pengaruhi penerapan hukum, pemahaman hukum yang kecil hendak mmpengaruhi penerapan hukum, bagus tingginya pelanggaran yang dicoba warga dalam penerapan hukum. ${ }^{4}$

Pada perbuatan Kejahatan Perampokan dengan pemberatan bahaya pidananya lebih dari pada 7 tahun, dalam perihal ini interogator berupaya buat mempraktikkan Artikel perbuatan kejahatan pencuruan enteng, supaya penanganan masalah perampokan itu bisa dicoba dengan cara diversi, begitu juga permasalahan diatas. Masalah perbuatan kejahatan Perampokan dengan kekerasan, yang terjalin pada hari Rabu bertepatan pada 24 Juni 2020 sekira Jam 04.00 Wib, yang bertempat di jalur Bos Gereja Kel Berok Nipah Kec Padang Barat Kota Padang. Begitu juga yang sudah diatur dalam Artikel 365 KUH Kejahatan Jo Undang- Undang RI Nomor. 11 Tahun 2012 mengenai Sistem Peradilan Kejahatan Anak. Bersumber pada hasil pengecekan penjelasan Saksi Korban, Saksi saksi, serta anak yang berkonflik dengan hukum MUHAMMAD RAYHAN Pgl RAYHAN Bin ZAINUL ARIFIN, dan benda fakta yang telah disita berbentuk berbentuk 1 (satu) bagian hp merek

\footnotetext{
${ }^{4}$ Ishaq, Dasar-Dasar Ilmu Hukum, Sinar Grafika, Jakarta, 2008,hlm. 248
} 
samsung A10 warna biru, 1 (satu) buah kotak hp merek Samsung A10 warna biru, 1 (satu) buah dompet levis warna coklat, 1 (satu) buah kartu ATM Bank BCA, 1 (satu) buah kartu ATM Bank MANDIRI, 1 (satu) buah kartu ATM Bank BRI, 1 (satu) bagian sepeda motor merek Suzuki Pahlawan FU warna putih gelap tanpa piringan hitam no polisi terpasang, hingga bisa didapat kesimpulan kalau memanglah betul anak yang berkonflik dengan hukum sudah melaksanakan perbuatan kejahatan Perampokan dengan kekerasan, yang terjalin pada hari Rabu bertepatan pada 24 Juni 2020 sekira Jam 04.00 Wib, yang bertempat di jalur Bos Gereja Kel Berok Nipah Kec Padang Barat Kota Padang.

kepada anak yang berkonflik dengan hukum dicoba penangkapan. Pada masalah ini korban tidak ingin dicoba diversi sebab berargumen angka kehilangan yang dideritanya lumayan besar. Hp yang dicuri meski sisa tetapi isi yang terdapat di dalamnya berharga besar. Untuk mempertanggung jawabkan perbuatannya, hingga anak yang berkonflik dengan hokum senantiasa meneruskan cara peradilan. Polisi selaku gapura awal yang menanggulangi anak yang berkonflik dengan hukum jadi determinan apakah seseorang anak hendak dilanjutkan ke cara peradilan ataupun aksi informal yang lain dalam perihal ini merupakan diversi.

Masalah perbuatan kejahatan Perampokan, yang terjalin hari Senin bertepatan pada 03 Juni 2019 sekira Jam 04.00 Wib, yang dikenal oleh korban pada hari jumat bertepatan pada 7 Juni 2019, yang bertempat di suatu rumah yang menetap di Komplek Gradasi Bagus Kel Air Pacah Kec Koto Tangah Kota Padang. Begitu juga yang sudah diatur dalam Artikel 363 Bagian (1) ke 4e KUH Kejahatan Jo Hukum RI Nomor. 11 Tahun 2012 mengenai Sistem Peradilan Kejahatan Anak. Anak melaksanakan perampokan pada malam hari. Benda benda yang didapat 1 (satu) bagian Tv LED merek Panasonic 32 inch warna gelap, 1 (satu) bagian Rice Cooker merek Yong Ma warna Gold, 1 (satu) buah kotak Tv LED merek Polytron 32 inch serta 1( satu) buah tabungan plastik yang sudah di potong. Untuk mempertanggung jawabkan perbuatannya, hingga anak yang berkonflik dengan hukum AGUNG Kesatu Pgl AGUNG Bin RENALDI bisa dicoba diversi sebab angka kehilangan yang tidak besar serta anak telah menangisi perbuatannya. Pada keadaan ini korban juga membenarkan buat dicoba diversi sebab seluruh benda yang dicuri sudah dikembalikan oleh terdakwa.

Tiap diversi yang menggapai kesuksesan dimana sudah terjalin perjanjian antara korban serta pelakon serta sudah timbulnya perjanjian diversi semacam pengembalian kehilangan, rehabilitasi kedokteran serta psikososial, penyerahan kembali ke orang berumur ataupun anak diserahkan pembelajaran di badan pembelajaran serta keselamatan sosial, dalam durasi sangat lama 3 (3) hari sehabis ketetapan diatas didapat, interogator harus memberi tahu ketetapan itu pada majelis hukum negara untuk menemukan penentuan dari majelis hukum negara serta dibikinnya sesuatu penentuan diversi.

Diversi yang kandas, ataupun tidak menggapai kesepakaran, penyidik hendak membuat informasi kegiatan diversi serta harus melaksanakan investigasi serta melimpahkan masalah ke kejaksaan dengan menyertakan informasi kegiatan diversi dan informasi riset warga dari aparat pekerja sosial ataupun Bapas. Bentang durasi buat dilakukanya diversi merupakan maksimum 7 hari sehabis dimulainya prnyidikan, serta cara diversi dicoba maksimum 30 hari sehabis dimulainya diversi. 
Terpaut diskresi yang dipunyai kepolisian yang diatur dalam Artikel 2 UU No 2 Tahun 2002 mengenai Kepolisian Republik Indonesia, yang mengatakan guna Kepolisian merupakan salah satu guna rezim negeri di aspek perawatan keamanan serta kedisiplinan warga, penguatan hukum, proteksi, dukungan, serta jasa pada warga, hendak namun dalam diversi interogator cuma menyediakan antara korban serta keluarganya dengan pelakon serta keluarganya. Interogator tidak bisa memohon para pihak buat balik kerak dengan alibi memesatkan cara penanganan masalah meski itu niatnya bagus. Perihal ini dimaksudkan buat melindungi marwah kepolisian yang sepanjang ini warga telah meragukan netralitas polisi, supaya polisi tidak dikira berat ataupun berpihak ke salah satu pihak, jadi polisi dilarang buat melaksanakan campur tangan, interogator haruslah senantiasa menjajaki serta meberikan apa yang di idamkan para pihak paling utama korban serta keluarga korban bersama pelakon serta keluarganya. Bila sudah digapai perjanjian perdamaian diantara kedua koyak pihak berikutnya pihak korban hendak mencabut informasi polisi serta polisi mengakhiri penyidikan.

Tahap-tahap diversi secara lengkap dimuat dalam TR/1124/XI/2006 dari Kabareskrim POLRI, 16 Nov 2006 dan TR/395/VI/2008 9 Juni 2008, tentang pelaksaan diversi dan restorative justice dalam penanganan kasus anak pelaku dan pemenuhan kepentingan terbaik anak dalam kasus anak baik sebagai pelaku, korban atau saksi.

\section{B. Kendala Yang Ditemui Penyidik Dalam Penerapan Unsur Tindak Pidana Pencurian Dengan Kekerasan Terhadap Pelaku Anak Oleh Penyidik Pada Satreskrim Polresta Padang Dalam Rangka Pertimbangan Alternatif Penyelesaian Perkara Anak}

Diversi dimaksudkan buat menjauhi serta menjauhkan anak dari cara peradilan alhasil bisa menjauhi stigmatisasi kepada anak yang berdekatan dengan hukum serta diharapkan anak bisa kembali ke dalam area sosial dengan cara alami. Oleh sebab itu, amat dibutuhkan kedudukan dan seluruh pihak dalam bagan menciptakan perihal itu. Cara itu wajib bermaksud pada terciptanya kesamarataan restoratif, bagus untuk anak ataupun untuk korban. Kesamarataan restoratif ialah sesuatu cara diversi ialah dimana seluruh pihak yang ikut serta dalam sesuatu perbuatan kejahatan khusus bersama- sama menanggulangi permasalahan dan menghasilkan sesuatu peranan buat membuat seluruh sesuatunya jadi lebih bagus dengan mengaitkan korban, anak, serta warga dalam mencari pemecahan buat membenarkan, perdamaian, serta mendinginkan batin yang tidak bersumber pada bayaran.

Tetapi pada penerapannya, dalam aplikasi faktor perbuatan kejahatan perampokan dengan kekerasan kepada pelakon anak oleh interogator pada Satreskrim Polresta Padang dalam bagan estimasi pengganti penanganan masalah anak mengalami bermacam hambatan, hambatan ini bisa bersumber dari interogator kepolisian, namun bisa pula berasal dari para pihak yang terpaut dengan masalah, ialah pihak keluarga pelakon anak ataupun pihak korban.

Disamping itu, ada pula sebagian hambatan yang ada pada hukum itu sendiri, alhasil ada sebagian bagian yang susah buat diaplikasikan dalam penindakan masalah anak. Ada pula bermacam aspek hambatan itu ialah: awal, perjanjian dalam konferensi susah digapai. Pertemuan antara keluarga pelakon anak dengan keluarga korban dalam penerapan konferensi kerap terjalin dalam atmosfer yang membentangkan, alhasil 
pertengkaran jadi gampang buat terjalin. Dalam perihal ini umumnya keluarga korban hendak lebih gampang buat terhasut, alhasil perjanjian rukun jadi susah buat digapai, serta konferensi bisa selesai pada situasi permasalahan yang terus menjadi meruncing.

Kedua, Stigma minus dari warga. Warga area pergaulan korban bisa pengaruhi pemikiran korban hal usaha diversi yang dikira warga selaku usaha buat mencegah pihak yang bersalah. Stigma minus dari warga kepada usaha diversi yang dicoba oleh interogator kepolisian dengan cara gampang pengaruhi korban alhasil mengalutkan dalam usaha pendekatan. Pasti perihal itu hendak jadi halangan menggapai titik temu antara kebutuhan korban dengan kebutuhan pelakon anak, yang berarti hendak menimbulkan konferensi jadi susah menciptakan perjanjian bersama.

Ketiga, Situasi ekonomi keluarga anak. Bila keluarga pelakon tidak sanggup melunasi ubah cedera dengan jumlah yang cocok hingga hendak susah mendapatkan persetujuan diversi dari korban perbuatan kejahatan. Keluarga korban tidak enggan buat bertahan menyangkal ubah cedera yang kurang pantas, terlebih bila situasi ekonomi korban terkategori bagus serta tidak sedemikian itu menginginkan ubah cedera yang relatif kecil.

Keempat, terdapatnya pemisahan ketentuan diversi. Terdapatnya pemisahan diversi cocok dengan persyaratan yang diresmikan sudah menimbulkan UU SPPA tidak seluruhnya bisa mencegah anak dari pengepresan psikologis dan raga, sebab sebagian permasalahan yang mengaitkan anak senantiasa wajib diproses lewat sistem peradilan kejahatan. Salah satu permasalahan yang terkendala dengan persyaratan diversi merupakan perbuatan kejahatan narkotika. Biar perbuatan kejahatan perampokan dengan kekerasan bisa diversi alternatifkan dengan Artikel 362. Perihal ini untuk Juri bersumber pada Perma No 4 tahun 2014. Jadi hambatan merupakan pada pengaturannya tidak seluruh perbuatan kejahatan anak bisa didiversi tetapi cuma yang dibawah 7 tahun.

Disamping itu pula diversi sendiri mempunyai keadaan yang membatasi penerapannya, ialah awal, Uraian warga kepada diversi serta restorative justice yang belum seluruh warga mengerti serta memahaminya, perihal ini terjalin sebab bisa jadi minimnya pemasyarakatan dari penguasa hal aplikasi diversi bersama profit dicoba diversi, kedua, Sulitnya membagikan uraian pada pihak korban dalam keluarga supaya menuntaskan masalah di kepolisian saja sebab terdapatnya korban yang kerap bersikukuh buat meneruskan ke Majelis hukum.

Ketiga, Warga umumnya kala terjalin sesuatu pelanggaran ataupun perbuatan kejahatan yang dicoba oleh anak mengarah langsung menuntaskan dengan sesama warga setempat, tetapi si anak selaku pelakon tidak merasa kapok serta melaksanakan perbuatan kejahatan kembali buat yang ke-2 sampai ke-3, alhasil menimbulkan dikala penanganan masalah anak itu dikala dicoba diversi keluarga korban amat menentang rukun dampingi pihak sebab keluarga sendiri telah merasa marah serta bosan atas aksi tersangka itu. Serta sebab dikala melaksanakan perbuatan kejahatan buat ke-2 serta ke-3 kalinya namun belum dicoba diversi atau cuma dicoba penanganan dengan sesama warga setempat, hingga anak sedang bisa dicoba diversi terhadapnya, Keempat, Warga sedang banyak yang belum yakin ketentuan penerapan diversi, pemahaman hukum warga yang sedang kecil kepada khasiat serta profit diversi menimbulkan minimnya keyakinan warga atas ke efektivan 
diversi, sementara itu diversi dirasa lumayan efisien kepada penanganan masalah anak di luar cara resmi.

Kelima, Susahnya mendatangkan saksi yang dapat membagikan penjelasan dikala cara diversi, sebab warga yang belum siuman hukummembuat paradigma kalau saat ini dapat saja jadi saksi, besok hari dapat pula jadi terdakwa. Keenam, Pendek cakap waktu durasi diversi membuat diversi dicoba terburu- buru.

Kasus dalam aplikasi Faktor Perbuatan Kejahatan Perampokan Dengan Kekerasan kepada Pelakon Anak selaku upaya estimasi alternative penanganan masalah oleh Interogator Pada Satreskrim Polresta Padang merupakan memperjuangkan supaya aksi kekerasan dalam melaksanakan perbuatan kejahatan ataupun pemberatan perbuatan kejahatan perampokan semacam dicoba pada malam hari dengan mengganggu amat susah buat disampingkan alhasil aksi itu cuma dikategorikan selaku perbuatan kejahatan perampokan lazim. Untuk mempraktikkan faktor perbuatan kejahatan perampokan lazim, butuh perjanjian serta persetujuan dari korban alhasil interogator bisa memilah alternative penanganan di luar pengadilan.

\section{KESIMPULAN}

Sedapatnya Penyidik melakukan fasilitasi antara korban dan pelaku sehingga pelaku anak dapat terhindar dari proses sistem peradilan pidana yang membuat trauma psikis bagi anak. Hal ini dapat dilakukan dengan meningkatkan profesionalisme penyidik dengan pelatihan dan pendidikan.

\section{DAFTAR PUSTAKA}

Abrianto Prakoso, Kriminologi dan Hukum Pidana Cet: 1, Laksbang Grafika,Yogyakarta, 2003.

Bambang Waluyo, Pidana dan Pemidanaan, Sinar Grafika, Jakarta, 2008.

Ishaq, Dasar-Dasar Ilmu Hukum, Sinar Grafika, Jakarta, 2008.

R. Abdoel Djamali, Pengantar Hukum Indonesia Edisi Revisi, Rajawali Pers, Jakarta, 2010. 